cent. HF) - "by leaving them in over night, but we prefer to clean with the stronger acid. The pickling vat is usually filled up with castings three times before it requires more acid.

"It takes sulphuric acid twice as long with the same proportion" - (that is, one to thirty would give a solution of about five and six-tenths per cent. sulphuric acid)-" and then does not eat into the corners as well as hydrofluoric acid; also wastes more iron and does not leave it bright."

For iron which is to be enameled, the cleaning with hydrofluoric acid is also advantageous, because it leaves a purer metallic surface than can be obtained with other acids.

I am informed that a large firm in this city is at present making arrangements with a view of throwing out their whole mechanical cleaning plant, in which they have been cleaning sixty tons a day.

Hydrofluoric acid or its salts are also used in distilleries to insure a more complete fermentation.'

The latest application, of which I heard only a few days ago, is for cleaning out oil and gas wells. It seems that the shooting of a well sometimes packs the rock so tightly that the hole is dryer after the shooting than before. By pouring about six barrels of hydrofluoric acid (I suppose the acid is used diluted) into the hole, which dissolves the silicates and afterwards is pumped out again, gas or oil get an outlet.

\title{
NITROGEN ASSIMILATION IN THE COTTON PLANT.
}

BY CHARIES E. COATES AND W. R. DODSON,

Recejved March 3, r895.

I the spring of 1895 , while looking up the literature of the cotton plant, it was noted that no quantitative work could be found touching the question of nitrogen assimilation in any member of the mallow family. As the cotton plant is highly nitrogenous in character and as there seemed to be no reason why the leguminoseae should have a prëemption claim on the absorption of free nitrogen, it was decided to undertake certain experiments along these lines, following Hellriegel's methods as far as possible, in the hope that something of importance might

1 Article of Dr. Leo Backeland, this Journal, I4, 212. 
be discovered concerning the relationships of cotton to atmospheric nitrogen. The conclusions of these experiments, however, were so entirely negative that this hope has been abandoned, and while, perhaps, they have not disproved the point in question absolutely, still it has been decided to put them on record in the belief that they afford at least strong evidence that cotton does not follow the legumes in this respect.

The method of work was as follows: A quantity of white sand was sifted through a one and a half mm. sieve, heated red hot in an iron pan and washed first with ordinary artesian water and afterwards with nitrogen-free water. Ten grams gave no nitrogen when analyzed by the usual Kjeldahl method. Ordinary flower pots were used, holding each about six pounds of sand. The sand had a water-holding capacity of about twenty-three per cent. It was kept moist to the extent of about seventy-five per cent. of its maximum capacity. The water used was obtained from artesian water nearly free from ammonia by distilling it and collecting only the middle third of the distillate. It gave merely traces of ammonia with Nessler's solution when analyzed in the usual way. A number of cotton seeds were linted as thoroughly as possible. The average weight of fiftyone seeds was 0 . I 66 gram. Of these, thirty-eight were weighed accurately and the weights of twenty fell between O.I IO gram and 0.130 gram. These twenty were soaked twenty-four hours in pure water, placed on moist sand in a dish, covered with a piece of filter paper, and the dish covered with a glass plate. As soon as a normal germ and rootlets appeared the seeds were planted in the pots, only those seeds being selected which showed about the same germinative energy. Before planting, four cc. of each of the following solutions were added to certain pots : potassium phosphate, 136 grams to liter; magnesium sulphate, I 20 grams to liter; potassium chloride, 74.5 grams to liter; and calcium chloride, 70.8 grams to liter. The seeds were planted about three-quarters of an inch deep in the sand and the pots were covered with cotton wadding until the plant appeared. They were kept in the open air and put under cover whenever it threatened rain. On one occasion a small quantity of rain fell on the pots. Otherwise they received only nitrogen- 
free water. The seeds were all planted on the first of May.

Pot 1 . - No nutriment was added to this pot. The plant was dead by May I 8 .

Pot 2.- Same as I. The plant was dead by May 28 th.

The growths were so little in $I$ and 2 that no analyses were made. To $3,4,5,6$, and 7 the solutions mentioned before were added. They were mixed, diluted to about $500 \mathrm{cc}$., mixed thoroughly with the sand in a porcelain dish and transferred to the pot before the seed was planted. After the plants had been growing a week or so, to 5,6 , and 7 there were added twenty-five cc. of a soil infusion, made as follows: A quantity of earth was taken from a field which had been planted in cotton for ten or twelve years. This earth was mixed thoroughly and 200 grams were shaken with one liter of water. After standing an hour or so, the clear supernatant liquid was decanted. A nitrogen determination gave 0.0002 gram nitrogen to twenty-five $\mathrm{cc}$. of this liquid. It was applied by a pipette to the roots of the plant while in the pot. The assumption was that any bacterial agencies which might affect the cotton plant would surely be present in the soil of the old cotton field. A similar method had proved efficacious in innoculating legumes.

Pot 3.-With mineral food-without soil infusion. The plant died about the last of May, apparently of nitrogen starvation.

Pot 4.-Same as 3. The plant lived until the close of June, but growth had ceased by June 15 . June 27 this plant and plants 5, 6, and 7 , were removed from the pots and analyzed as follows: The sand was washed carefully from the roots, the entire plant was dried at $100^{\circ}$, and the nitrogen determined by the Kjeldahl method. In this case the seed weighed 0.1300 gram. A series of analyses had given 3.07 per cent. nitrogen in the whole cotton seed.

Nitrogen in

Nitrogen in seed of $4 . \ldots \ldots \ldots \ldots \ldots \ldots \ldots \ldots \ldots . .6 \ldots \ldots$

Dry matter in seed of $4 \ldots \ldots \ldots \ldots \ldots \ldots \ldots \ldots \ldots, 0.5050$

Nitrogen found in seed of $4 \ldots \ldots \ldots \ldots \ldots \ldots \ldots \ldots .0 .0068$

Pot 5.-With mineral food, plus soil infusion. 
Seed weighed $\ldots \ldots \ldots \ldots \ldots \ldots \ldots \ldots \ldots \ldots \ldots \ldots, 0.1244$

In seed nitrogen $\ldots \ldots \ldots \ldots \ldots \ldots \ldots \ldots \ldots \ldots \ldots, 0.0038$

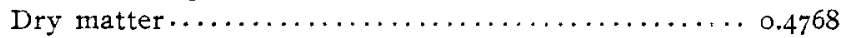

Nitrogen found.......................... 0.0056

Pot 6.-Same as 5 .

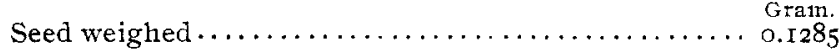

In seed nitrogen $\ldots \ldots \ldots \ldots \ldots \ldots \ldots \ldots \ldots \ldots \ldots \ldots . .0039$

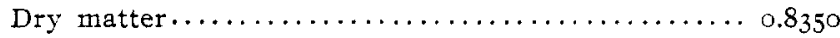

Nitrogen found $\ldots \ldots \ldots \ldots \ldots \ldots \ldots \ldots \ldots \ldots \ldots \ldots, 0.0074$

Pot 7.-Same as 5 and 6.

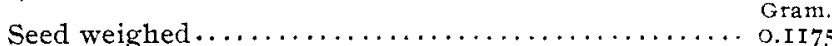

In Ieed

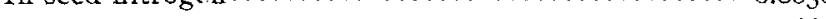

Dry matter.................................. 9664

Nitrogen found $\ldots \ldots \ldots \ldots \ldots \ldots \ldots \ldots \ldots \ldots \ldots, 0.0080$

In all these instances growth had stopped before the plants were removed from the pot. The gain in nitrogen without soil infusion was 0.0028 gram; with soil infusion, $0.0018,0.0035$, and 0.0044 gram. Apparently it mattered very little whether the soil infusion was added or not and in all the instances the gain was so inconsiderable as to lie well within the limits of error of the experiments. It would seem therefore that under the conditions employed the cotton plant does not assimilate atmospheric nitrogen.

CHEMICAL LABORATORY

I.OUISIANA STATE UNIVERSITY.

[CONTRIBUTIONS FROM THE CHEMICAL LABORATORY OF THE U. S. DEPARTMENT OF AGRICUITURE, No, I9.]

\section{DETERMINATION OF LACTOSE IN MILKS BY DOUBLE DILUTION AND POLARIZATION.}

BY H. W. WILEY AND E. E. EWELl.

Reereivd March zo, 5896 .

I volume 6, page 289, of the American Chemical Journal, one 1 of us (Wiley) published an article on the determination of lactose in milks by optical methods. The principal novelty in this process was the substitution of mercuric nitrate as the reagent for precipitating proteids in place of the other reagents which had usually been employed for that purpose. By the use of mercuric nitrate in an acid solution, it was shown in that 